\title{
THE OCULAR MANIFESTATIONS OF NUTRITIONAL DISEASE
}

\author{
D. S. McLaren, M.D. (Edin.), Ph.D. (Lond.), \\ D.T.M. \& H. (Eng.). \\ Research Professor of Clinical Nutrition.
}

\author{
A. Halasa, M.D. (Beirut), M.S. (Iowa). \\ Assistant Professor of Ophthalmology, \\ Department of Ophthalmology.
}

School of Medicine, American University of Beirut, Beirut, Lebanon.

MALNUTRITION as a cause of blindness has been and still is, much underestimated. In many countries it is the chief cause of blindness in young children. The onset is insidious and difficult to diagnose and the later stages proceed rapidly to irreversible damage. Opthalmologists have tended not to be particularly interested in conditions that do not make demands on their diagnostic or surgical skill and nutritionists have fought shy of such a specialized organ as the eye. It is however, of great importance that doctors trained in Europe and North America and going to work abroad should be prepared to deal with the medical problems as they exist there. They will find malnutrition rife in all its forms with eye involvement meriting their close attention. Furthermore, in all spheres of medical practice, it should be realised that on occasion malnutrition may be the cause of visual symptoms as for example in states of malabsorption, chronic alcoholism and when vitamins are inadvertently omitted from anti-allergenic infant formulae.

The association of visual impairment and poor diet has long been recognised. Accounts of prolonged sieges, sea voyages, religious fasts and severe seasonal shortage of food and famines record the frequent occurrence of outbreaks of night blindness under these conditions. Among the earliest of all medical writings such as the Ebers papyrus (circa 1600 B.C.) and Chinese treatises of a similar period are to be found the well-known prescriptions of liver for night blindness and other eye diseases. The approach in these times, however, appears to have been a purely empirical one as the part played by poor diet was not known. It was not until the 19th century that xerophthalmia began to emerge as a clinical entity with its characteristic pathology, symptomatology and aetiological relationship to dietary deficiency. In the first quarter of the 20 th century reports of the frequent occurrence of xerophthalmia and keratomalacia in Japan,
Indonesia, India and elsewhere showed it to be a serious problem in many parts of the world. The discovery of fat-soluble vitamin A and the demonstration of its efficacy in the Danish outbreak during the first world war as well as in induced deficiency in experimental animals proved that the early retinal dysfunction and later corneal damage were both caused by vitamin A deficiency.

In all probability another nutritional condition affecting the eyes lies inseparable from vitamin A deficiency among the early accounts. Nutritional amblyopia or retrobulbar neuropathy, resulting from deficiency of vitamins of the B complex, now appears to form a feature of some early accounts of pellagra and beriberi and reached epidemic proportions in some Far Eastern prisoner-of-war camps during World War II.

Both these nutritional diseases causing blindness are serious problems in many parts of the world at the present time. They will be considered in more detail now, together with the role of malnutrition in certain other eye diseases. Detailed treatment of the historical aspects of this subject may be found elsewhere (Oomen, 1961, McLaren, 1963).

\section{Vitamin A Deficiency}

All too often the physician teids to forget that severe vitamin A deficiency is a generalized disease, affecting especially epithelial tissues throughout the body. Recent work suggests that, outside the retina, vitamin A is chiefly concerned with mucopolysaccharide synthesis and stability of lysozome membranes. Children aged three months to four years are most commonly affected. Thousands continue to go blind every year throughout the world from this cause alone. (Oomen, McLaren, Escapini, 1964). The problem is especially serious in most of the countries of South and East Asia, and in some countries in the Near East, North Africa, Central and South America. The term "xerophthalmia" has been adopted by WHO 
TABLE I

\section{THE AGE SPECTRUM OF VITAMIN A DEFICIENCY}

\begin{tabular}{|c|c|c|}
\hline $\begin{array}{l}\text { Stage } \\
\text { Pregnancy }\end{array}$ & $\begin{array}{l}\text { Pathogenic factors } \\
\text { Basic diet low in vitamin A } \\
\text { (mostly carotene) } \\
\text { Increased requirements } \\
\text { Food taboos }\end{array}$ & \begin{tabular}{l}
\multicolumn{1}{c}{ Manifestations } \\
Low plasma vitamin A \\
Low liver stores \\
Bitot's spots (occasional) \\
Xerophthalmia (rare)
\end{tabular} \\
\hline Fetus & Strain of repeated pregnancies & $\begin{array}{l}\text { Low liver stores } \\
\text { Xerophthalmia (rare) } \\
\text { ? Abortion } \\
? \text { Congenital malformations }\end{array}$ \\
\hline $\begin{array}{l}\text { 1st year } \\
\text { of life }\end{array}$ & $\begin{array}{l}\text { Breast milk: low concentration, } \\
\text { diminished volume } \\
\text { Artificial feeding } \\
\text { Maternal neglect } \\
\text { Infections }\end{array}$ & $\begin{array}{l}\text { Lowering of plasma vitamin A } \\
\text { Depletion of liver stores } \\
\text { Xerophthalmia and keratomalacia } \\
\text { (relatively common) } \\
\text { Xerosis conjunctivae and Bitot's } \\
\text { spots (rare) }\end{array}$ \\
\hline $2-5$ years & $\begin{array}{l}\text { Prolonged breast feeding } \\
\text { Supplementation with foods low } \\
\text { in vitamin A } \\
\text { Deposed child situation } \\
\text { Infections }\end{array}$ & $\begin{array}{l}\text { Peak incidence of xerophthalmia } \\
\text { and keratomalacia } \\
\text { Xerosis conjunctivae and Bitot's } \\
\text { spots (not uncommon) } \\
\text { Fundus changes }\end{array}$ \\
\hline School age & $\begin{array}{l}\text { Diet low in vitamin A (mostly } \\
\text { carotene), fat, and protein } \\
\text { Infections }\end{array}$ & $\begin{array}{l}\text { Xerosis conjunctivae and Bitot's } \\
\text { spots predominate } \\
\text { Night blindness } \\
\text { Fundus changes }\end{array}$ \\
\hline Adult & $\begin{array}{l}\text { As above plus special privation } \\
\text { (famine, prison) }\end{array}$ & $\begin{array}{l}\text { Night blindness predominates } \\
\text { Bitot's spots (occasional) } \\
\text { Keratomalacia (rare) }\end{array}$ \\
\hline
\end{tabular}

From McLaren, D. S. Malnutrition and the Eye, New York, Academic Press, 1963 p. 196.

as the most convenient one available to denote the severe deficiency state. Many patients do not survive but succumb to such infections as gastroenteritis, measles and other respiratory conditions which play an integral part in the causation of xerophthalmia, together with the everpresent protein malnutrition, of kwashiorkor or marasmic type. In a detailed study in Jordan of 18 hospitalized cases of xerophthalmia we had a mortality of more than $80 \%$ despite large doses of promptly administered vitamin $\mathrm{A}$ and attention to dehydration and accompanying infections. In a similar group of malnourished children but with no clinical or biochemical evidence of vitamin A deficiency the mortality was only $15 \%$. (McLaren, Tchalian and Shirajian, 1964).

The accompanying table shows how various factors play a part in the pathogenesis of the disease at different ages and how the most severe eye lesions are found in the youngest groups.

\section{Night blindness}

In co-operative subjects impairment of scotopic vision due to vitamin A deficiency can be detected by rod scotometry or dark adaptome- try before the subject is aware that he is no blind. The electroretinogram may also swow changes at this stage. There is unfortunately at present no practical visual test that might be applied to young children in the susceptible period to diagnose the condition at this ear stage before the anterior segment of the eye undergoes the changes of xerosis. Plasma leves of the circulating vitamin are not of help in early diagnosis as there is poor correlation between them and the eye signs except in the most advanced stage. For instance, we found (Halasa and McLaren 1964) low blood levers of vitamin A (below $20 \mu \mathrm{g}$. $100 \mathrm{ml}$.) in $39 \mathrm{out}$ of 58 marasmic children examined in Beiriat although in none was there any conjunctiva $\bar{P}$, corneal or fundus change attributable to vitami A deficiency.

It has been claimed that certain changes the fundus accompanying night blindness and conjunctival xerosis respond to vitamin A (Teng-Khoen-Hing, 1959). Their existence is nd in doubt; they have been carefully photes graphed, and resemble closely the appearange of the fundus in retinitis punctata albescers and fundus albi punctatus, but their precise 


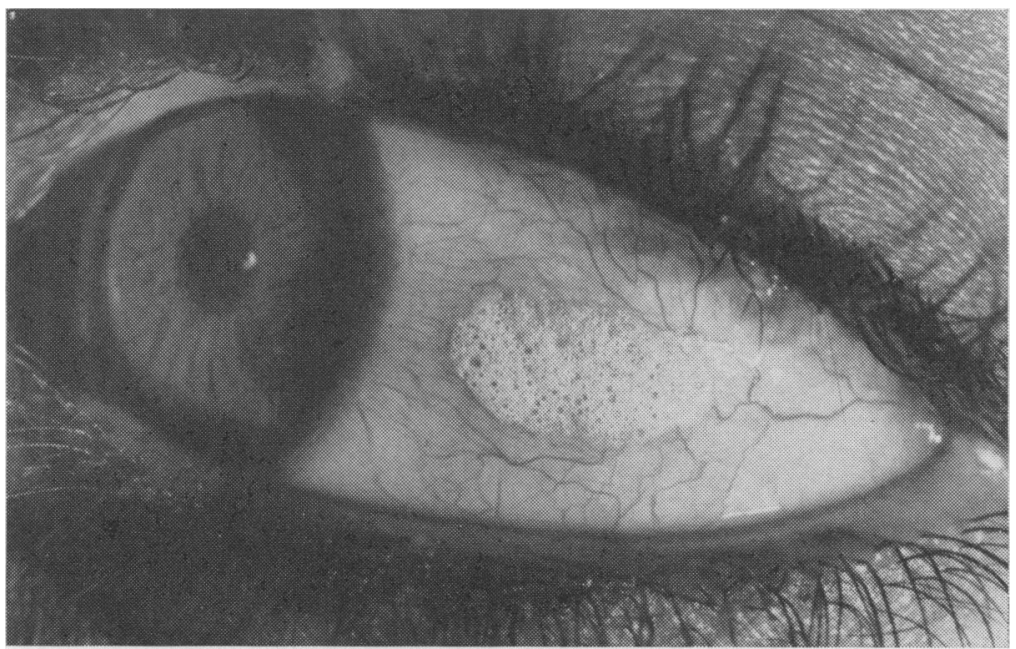

Fig. 1.-Typical foamy Bitot's spot in an eight years old Tanganyikan boy.

relationship to vitamin A deficiency still remains to be elucidated.

Night blindness, per se, is not pathognomonic of vitamin A deficiency, being also a feature of various eye diseases e.g. retinitis pigmentosa, Oguchi's disease, choroideremia, gyrate atrophy of the choroid and retina, onchocerciasis and occasionally congenital. If nutritional in origin the symptom will disappear after consumption of about 30,000 I.U. of vitamin A daily administered as cod or halibut liver oil.

\section{Conjunctival xerosis and Bitot's spot}

If vitamin A deficiency persists the anterior, as well as the posterior, segment of the eye becomes affected. The bulbar conjunctiva becomes dry, thickened and wrinkled with loss of normal transparency, increase in pigmentation and failure of the surface to be wetted by tears. These changes result from keratinization of the epithelial cells and are usually most marked in the area situated in the interpalpebral fissure where exposure and trauma undoubtedly play some part. It is not possible from a study of the conjunctival changes alone to know whether vitamin A deficiency has caused them.

Bitot's spot (Fig. 1) has long been associated with night blindness and vitamin A deficiency. It consists of a whitish or grayish plaque of desquamated epithelial cells with a foamy surface usually situated close to the limbus on the exposed part of the bulbar conjunctiva more commonly temporal than nasal. Broadly speaking there appear to be two types of
Bitot's spot from the point of view of causation. Small isolated spots, in older children and adults with good dietary histories, no complaints and normal plasma levels of vitamin A, do not respond to vitamin A therapy and appear to result chiefly from local factors. On the other hand, more diffuse spots or patches of material, in young children with other evidence of xerophthalmia and low levels of vitamin $\mathrm{A}$ in the plasma, usually respond to treatment together with the other signs of deficiency.

\section{Corneal xerosis and keratomalacia}

Xerosis of the cornea has the same characteristics as xerosis of the conjunctiva and is indicative of a more advanced stage of the deficiency. In addition there is infiltration of the stroma, the whole cornea taking on a bluish hazy appearance, and there may be minimal vascularization.

Before long loss of substance of the cornea and deformity commence. At this advanced stage a characteristic liquefactive process, known as "colliquative necrosis" is responsible for the irreversible corneal damage that results in varying degrees of visual impairment. At first an excavation, what may be called an "ulcer" for want of a better term, occurs in the central part of the cornea and results in any degree of loss in depth of corneal tissue. In advanced cases corneal perforations, iris prolapse and even loss of vitreous and extrusion of the lens may result. When this process involves the whole cornea it is called keratomalacia (Fig. 2). 


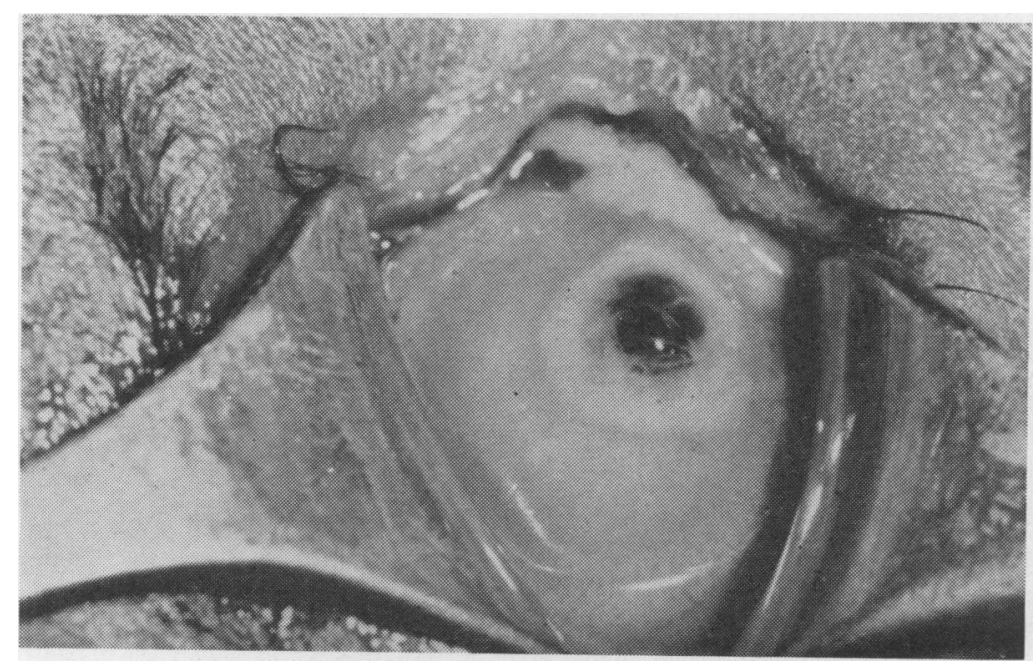

FIG. 2.-Keratomalacia with complete liquefactive necrosis of the cornea in a Jordanian infant of five months.

It proceeds very rapidly, often without any reaction or inflammation, the corneal structure melting into a cloudy gelatinous mass which may be dead white or dirty yellowish in colour.

In untreated cases endophthalmitis not infrequently supervenes. If the patient survives there may be a combination in the two eyes of a whole range of residual damage from the finest nebulae through dense, partial, total leucomata, to phthisis bulbi or anterior staphyloma. The minimal vascularization of the corneal scar is usually a striking feature of those resulting from uncomplicated vitamin A deficiency. Fortunately the two eyes are frequently affected to a widely differing degree so it is often possible to save sight, at least in one eye. From our experience in Jordan we recommend that vitamin $A$ be given to the severe case by mouth, by intra-gastric tube if necessary, as absorption is best by this route and by intramuscular injection also, to ensure that the child does get the vitamin. By both routes aqueous dispersions are better utilized but are, unfortunately, not generally available, the palmitate in oil being the usual form. By each route the dose should be calculated on the basis of actual body weight and 5,000 I.U./Kg./ day be given by each route for three days, thereafter continuing with cod liver oil by mouth.

\section{Hypervitaminosis $A$}

Among the rather bizarre collection of symptoms resulting from toxic doses of vitamin $\mathrm{A}$ some are ocular. In acute toxicity, diplopia and 울 lights before the eyes in adults and papile loedema accompanying an increase of intra cranial pressure in children and adults hav\& been the most frequent. Fear of inducing condition by the vigorous treatment of xegophthalmia is unfounded.

More and more cases of chronic hyperit vitaminosis $A$ are being reported, usua fll occuring in young children given 100,000 I.U or more daily for many months. Papillœdemaō extra-ocular paralyses, diplopia, exophthalmos and superficial retinal haemorrhages are among the ocular features reported.

Physicians and public alike, in this vitamin conscious era, need to be made aware of the dangers of excessive dosage of vitamin A.

\section{Nutritional Retrobulbar Neuropathy}

This condition has been endemic in certain parts of the West Indies, West Africa and Indiao for many years and also occurred in epidemic proportions in the Far Eastern prisoner-of-war? camps during the second world war (Smith ands Woodruff, 1951). The precise cause is not known but most investigators are agreed thatr it is nutritional and usually responds to some of the $B$ complex of vitamins. Thiamine, $N$ riboflavin and vitamin $B_{12}$ have all been claimed to be effective. Frequently the besto results are obtained with multi-B complexo therapy and this is reasonable as these vitamins frequently occur together in nature. 
The amblyopia that occurs in chronic alcoholism and tobacco addiction is identical in symptomatology and the pathological changes it produces. (Victor, Mancall and Dreyfus, 1960). Vitamin $B_{12}$ appears to be especially effective (Heaton, McCormick and Freeman, 1958). This type of amblyopia is also due to malnutrition, but secondary to the anorexia, chronic gastritis and other metabolic effects of the addiction.

Nutritional amblyopia produces blurring of vision for both near and distant objects, frequently accompanied by photophobia and retrobulbar pain. Examination of the visual fields reveals central or centrocaecal scotomata with little or no contraction at the periphery. Based on the experience of the many hundreds of cases followed up after the last war it appears that all degrees of visual disability result, short of complete blindness. Other cranial nerves, especially the auditory and oculo-motor are often involved. Exaggerated reflexes, muscles wasting and sensory losses in limbs are frequent. Skin and mucous membrane changes suggestive of vitamin B complex deficiency may be found in the same patients.

\section{Other Eye Conditions Attributed to Vitamin B Complex Deficiency}

There has been described a superficial keratitis which has been termed "corneal epithelial dystrophy". It was reported in some prisoner-of-war camps and was apparently identical with an endemic disease of the cornea found in Trinidad and the Philippines. One of us (McLaren, 1963) has suggested that this is not a nutritional condition but indistinguishable from epidemic keratoconjunctivitides of viral aetiology.

The eyes are commonly affected in Wernicke's encephalopathy due to acute deficiency of thiamine (de Wardener and Lennox, 1947). Like nutritional amblyopia, this has occurred under conditions of privation, as in prison camps, and is also seen in the terminal stages of chronic alcoholism. Nystagmus is an invariable and helpful diagnostic feature, being also one of the earliest manifestations. Other eye signs include fatigue and paralysis of the external rectus muscles, paralysis of conjugate horizontal gaze, loss of visual acuity and papillœedema. A similar state has also been attributed to deficiency of nicotinic acid.

Other conditions that have been reported include fundus changes in infantile beriberi, riboflavin-responsive impairment of dark adap- tation, a disturbance of vitamin $B_{12}$ metabolism in diabetic retinopathy, and widespread haemorrhages in the retina in megaloblastic anæmias of nutritional origin.

\section{Inanition and starvation}

In comparison with other organs of the body the eye appears to be remarkably well protected against the adverse effects of general undernutrition. This may well have something to do with the advanced stage of development reached by the eye at even the time of birth and to the great functional significance of the eye for survival. Most of the studies carried out on starved individuals immediately after the second world war did not reveal much evidence of eye involvement. Notable exceptions however are the condition attributed to starvation in the civilian population of Athens termed "superficial polymorphous keratopathy" (Djacos, 1949) and certain changes in the fundus such as narrowing of the retinal arteries, œdema of the optic disc and white or yellowish spots on the retina reported in prisoners of war in Germany and Russia.

\section{Other nutrients}

There is little evidence that imbalance of nutrients, other than those dealt with above, plays any part in the causation of human eye disease. However, attention may be drawn to the association of zonular cataract and the hypocalcaemia of tetany, the possible relationship of retinal haemorrhages in the newborn infant and maternal deficiency of vitamin $\mathrm{K}$, the defect in dark adaptation reported in some patients with zinc deficiency secondary to liver disease, and the occurrence of bright orangecoloured plaques, possibly of cholesterol, at the bifurcation of retinal arterioles in some patients with atherosclerosis in which dietary fat is thought to play some ætiological role.

\section{Malnutrition and Certain Eye Diseases \\ Discrete colliquative keratopathy}

This is the name given by one of us (McLaren, 1963) to a mysterious disease of the cornea described originally in malnourished children in South Africa. In the typical case there is a quiet and discrete dissolution of one small part of the cornea frequently followed by prolapse of the iris. Although it has hitherto been maintained that this is a separate entity and distinct from the keratomalacia of vitamin A deficiency one is left wondering whether they might not after all turn out to be one and the same condition once a thorough nutritional and 
biochemical evaluation were made of the African cases. The poor dietary background and generally malnourished condition is certainly suggestive of this.

\section{Trachoma}

While it is true that trachoma is common among communities that are malnourished there is no proof that nutritional factors per se play any part. From purely clinical evidence it seems that the corneal complications of trachoma progress more rapidly in the malnourished but on the other hand it has also been suggested that marasmic children are often not affected in communities where trachoma is rife among the more healthy members. It is possible that certain enzyme systems essential for the virus are lacking in the malnourished conjunctiva. In Jordan, where both vitamin A deficiency and trachoma co-exist among many of the poorer sections of the population, follicle formation in the palpebral conjunctiva has been noted in association with xerosis and Bitot's spots on the contiguous bulbar conjunctiva, making the significance of these latter signs difficult to interpret.

\section{Cataract}

In experimental animals cataract has been induced by diets deficient in protein, individual amino-acids and riboflavin. There is a good deal of circumstantial evidence that senile cataract has a high incidence, an early age of onset and possibly tending rather commonly to be nuclear in origin in places like India where the above-mentioned nutrients are in short supply. Children who have recovered from severe protein malnutrition (kwashiorkor) do not have evidence of early cataract but it is possible, although difficult to prove that they might be candidates for cataract later in life. (McLaren, 1963).
Refractive errors

Although the refractive state of the ey appears to be very largely under genetic con trol (Sorsby, Sheridan and Leary, 1962) ther is evidence that environmental factors maf have some influence. We have shown that marasmic infants tend to be myopic and that after recovery their refraction returns to more normal levels (Halasa and McLaren, 1964 Premature infants are more myopic than those born at full term (Graham and Gray, 1963) One of us (McLaren, 1960, Johnstone and McLaren, 1963) reported a high incidence of myopia in school children who had passe $\Phi$ through a severe famine in Tanganyika although the refraction of similar tribes in othes parts of the country where there had been ng famine was normal. All these results poin in the same direction but need further carefun investigation.

\section{Summary}

Xerophthalmia is still a major cause of blindness in many parts of Asia, Africa and Latin America. In the most susceptible age group, the young child, it accounts for the major proportion of blindness in these areas and the underlying vitamin A deficiency cono tributes considerably to the high childheg $\Phi$ mortality.

Nutritional retrobulbar neuropathy, tobacếoalcohol amblyopia, certain encephalopatises and some diseases affecting the cornea sre due to deficiency of $\mathrm{B}$ vitamins. Under con ditions of special privation and in certain ens demic foci they are of considerable importance

Much remains to be learned about the role of malnutrition in the pathogenesis of other eye conditions.

The original work referred to in this paper was supported by U.S. Public Health Service Grants AM 05285 and 06735 from the Institute of Arthritis and Metabolic Diseases.

\section{REFERENCES}

DE WARdener, H. E., and LenNox, B. (1947): Cerebral Beriberi (Wernicke's encephalopathy) Review of 5 Cases in Singapore Prisoner of War Hospital. Lancet, i, 11.

Djacos, C. (1949): Les Altérations Oculaires dans les Oedèmes de Carence, Arch. Opthal. (Paris), 9, 421.

Graham, M. V., and Gray, O. P. (1963): Refraction of Premature Babies' Eyes, Brit. med. J., i, 1452.

Halasa, A., and McLAREN, D. S. (1954): The Refractive State of Malnourished Children, Arch. Ophthal., 71, 827.

Heaton, J. M., MoCormick, A. J. A., and Freeman, A. G. (1958): Tobacco Amblyopia: A Clinical Manifestation of Vitamin $B_{12}$ Deficiency, Lancet, ii, 286.

JohnStone, W. W., and McLAREN, D. S. (1963): Refraction Anomalies in Tanganyikan Children, Brit. J. Oph thal., 47, 95.

MCLAREN, D. S. (1960): Nutrition and Eye Disease in East Africa: Experience in Lake and Central Prove inces, Tanganyika, J. trop. Med. Hyg., 63, 101.

MCLAREN, D. S. (1963): Malnutrition and the Eye, p. 162, New York: Academic Press.

Mclaren, D. S., Tchalian, M., and Shirajian, E. (1964): Xerophthalmia in Jordan. Amer. J. clin. Nutr., i the press.

OOMEN, H. A. P. C. (1961): An Outline of Xerophthalmia, Int. Rev. trop. Med., 1, 132.

OOMEN, H. A. P. C., McLaren, D. S., and Escapini, U. (1964): Xerophthalmia: the Public Health Aspects of

Vitamin A Deficiency. W.H.O.-limited circulation report in the press. Med. Res. Coun. (Lond.), No. 274.

Sorsby, A., Sheridan, M., and LeARY, G. A. (1962): Refraction and its Components in Twins, ibid, No. 303.

Teng-Khoen-Hing (1959): Fundus Changes in Hypovitaminosis A. Ophalmologica (Basel), 137, 81.
Victor, M., Mancall, E. L., and Dreyfus, P. M. (1960): Deficiency Amblyopia in the Alcoholic Patient-a Clinicopathologic Study, Arch Opthal, 64, 1. 